\title{
Study on Visual Situation-problem-based Teaching Design in Data Structure
}

\author{
Maochun $\mathrm{Yu}$ \\ College of Education \\ Yanbian University \\ Yanji, China 133000
}

\begin{abstract}
The rapid development of information technology has provided many ways for the reform of educational methods. This article takes data structure course as an example, and makes deep research from the teaching resources making software, the creation of visual situation problems, the design of teaching process, the construction of teaching resources and the release of teaching resources. And then, it summarizes the general methods and process of visual situation-problem-based teaching design of arithmetic knowledge points, which can provide reference for teachers to change the teaching methods under the environment of Internet and education.
\end{abstract}

Keywords—data structure; visualization; situated-problem; teaching design

\section{INTRODUCTION}

In the course of data structure, it can transform the problems in the life into the models that can be solved in computer language. This course is offered in most science and engineering departments in colleges and universities. Most of the teachers in this course use the method of "teaching-acceptation" to teach students. The teaching content is out of production and real life, obscure and difficult. Students can't use what they have learned in the practice. When they are employed, the students are hard to meet the needs of employers. And the data structure is recognized as a difficult course. And then, it has made visual situation-problem-based teaching design of abstract knowledge points of the data structure through the practice in this article. It has summed up the visual situation-problembased teaching design methods of abstract knowledge points. It provides references for the majority of teachers and scholars.

\section{The SitUATED-PROBLEM TEACHING METHOD}

According to the teaching points, the teachers design various visual situations, identify problems, and guide the students to deal with the problems. Then, the students can have the learning effectively. That is the situated-problem

*Fund Project: This article is the phased research result of education and science research project of Yanbian University in 2016. And this research is on the construction of MOOC and teaching practice of general courses under the environment of Internet and education (Project No.:GJ2016016) teaching method.

At the beginning of the 20th century, American educator, Dewey put forward the concept of problem-based teaching. He believed that the effective learning process was to create problem situations for students. Then, the students can have the progress through solving problems. In the problem-based pedagogy, Bruner pointed out that the students could learn valuable experience in the problem situations. In the 1980s, Brown explained the Situated Cognition and Learning in his published thesis, which was the theoretical support of situational teaching.

Domestic scholars started the research of the situatedproblem teaching method lately. Li Jilin firstly established the theoretical system of the situated-problem teaching method [1], and successfully applied it in Chinese subject to promote the development of the situated-problem teaching method in China. In Guizhou province, Lv Chuanhan carries out the research of "setting the mathematical situationputting forward the issue of mathematics" [2]. And he applies the situated-problem teaching theory to the practice. Luo Zengru puts forward that a lot of mathematical knowledge points need to use the situated-problem teaching method to design cases. The students would use mathematical knowledge in life to make calculation and deal with practical problems [3]. In Peng Yufeng's article, he pointed out that in the aspect of liberal arts, the situatedproblem teaching is based on the situational teaching theory, and it focuses on the classroom atmosphere. In science, the situated-problem teaching is based on the solution of problems. And it mainly focuses on the cultivation of students' abilities [4].

Most domestic researches on situational teaching aim at the creation of situations in classroom language teaching, which are mostly concentrated in the design of the introduction of the classroom. However, there are relatively few situation problems designed for the knowledge points of the whole lesson. And most of the studies on visual teaching are mind-mapping visualization, such as Li Mang [5], Zhao Huichen [6] and other scholars' researches, and there are few studies on the visualization of the situations. 


\section{ThE DESIGN PRINCIPLES OF VisUAL SitUATION- PROBLEM-BASED TEACHING}

Based on the production of visual situation-problembased teaching materials for most knowledge points of the data structure, this paper concludes that visual situationproblem-based teaching design of data structure course should follow the following principles:

- The learners can learn knowledge independently: The knowledge points could be designed into MOOC or Micro-course form for students to learn independently.

- The creation of the situations and problems should be related with the learners' living practice: People would understand and accept the things they are more familiar with. Therefore, in the designs of the situations, we must combine it with the learners' living practice closely with the utilization of common and popular situations as the import introduction links.

- The created situations and problems could go throughout the learning process: When the students learn new knowledge points, the teachers could make the introduction with the situations. They can guide the students to learn by asking questions. After the learning, the students should be able to use the knowledge to solve the proposed problems. The whole teaching design must be a complete entirety, and the situations run through the whole learning.

- The created situations should be universal, and the learners can infer other things from one fact. And the learners also can think of more and more examples of knowledge applications.

- The created situations could be achieved easily in the technical means

\section{B. The Teaching Script Design of "Minimum Spanning Tree"}

TABLE I. The TEAChing SCRIPT OF "Minimum SPANNING TREE"

\begin{tabular}{|c|c|c|c|}
\hline No. & Frame & Caption & The Sound of Lines \\
\hline 1 & $\begin{array}{l}\text { to virtualize the situation background, to } \\
\text { draw the animation title with hands }\end{array}$ & $\begin{array}{l}\text { "Data Structure Course" } \\
\text { minimum spanning tree }\end{array}$ & Background music \\
\hline 2 & the pictures of future city, text animation & future city & the horn of cars \\
\hline 3 & $\begin{array}{l}\text { the combination of elite group pictures and } \\
\text { the animation effect of teachers }\end{array}$ & the elite groups & We haven't taken a task for a long time. \\
\hline 4 & The correspondent comes on stage. & Leader, the task comes. & Leader, the task comes. \\
\hline 5 & Map and the correspondent & Laying smart optical cable & $\begin{array}{l}\text { The supervisors want us to lay smart optical cable among these } \\
\text { cities. }\end{array}$ \\
\hline 6 & Map and the leader & How to select the routes? & How to choose the routes among these cities? \\
\hline 7 & $\begin{array}{l}\text { With the appearance of the teachers, the } \\
\text { background is still the background of the } \\
\text { elite group }\end{array}$ & I'll solve this problem. & I'll solve this problem. \\
\hline 8 & $\begin{array}{l}\text { Teacher appears, and the background is } \\
\text { the map. }\end{array}$ & minimum spanning tree & We can solve this problem with the minimum spanning tree. \\
\hline 9 & $\begin{array}{l}\text { Teacher appears, and the background is } \\
\text { the PPT of the concept of minimum } \\
\text { spanning tree }\end{array}$ & $\begin{array}{l}\text { The smallest sum of the cost of } \\
\text { all sides in all the spanning trees } \\
\text { of the connected network is called } \\
\text { the minimum cost spanning tree. }\end{array}$ & $\begin{array}{l}\text { Among the spanning trees of a connected network, the spanning } \\
\text { tree with the lowest cost of each side is called the minimum cost } \\
\text { spanning tree (MST) of the connected network. } \\
\text { The spanning tree with the smallest cost of each side is the route } \\
\text { that we have to choose to lay fiber optic cable. }\end{array}$ \\
\hline
\end{tabular}




\begin{tabular}{|c|c|c|c|}
\hline No. & Frame & Caption & The Sound of Lines \\
\hline 10 & Financier appears & $\begin{array}{l}\text { The characteristics of the minimum } \\
\text { spanning tree }\end{array}$ & $\begin{array}{l}\text { What are the characteristics of the minimum spanning } \\
\text { trees? }\end{array}$ \\
\hline 11 & $\begin{array}{l}\text { Teacher appears, and the background is the } \\
\text { map. }\end{array}$ & Vertex collection & $\begin{array}{l}\text { Before learning the characteristics, it should firstly find } \\
\text { out the vertex set and the set of edges in this map. Look } \\
\text { at the map, it is a connected map. }\end{array}$ \\
\hline 12 & $\begin{array}{l}\text { Teacher appears, and the background is the } \\
\text { map with the vertexes. }\end{array}$ & $\mathrm{V}=\{\mathrm{A}, \mathrm{B}, \mathrm{C}, \mathrm{D}, \mathrm{E}, \mathrm{F}, \mathrm{G}, \mathrm{H}, \mathrm{I}\}$ & In this map, all the vertices form a vertex set $\mathrm{V}$. \\
\hline 13 & $\begin{array}{l}\text { Teacher appears, and the background is the } \\
\text { map with the vertexes and the edges. } \\
\text { Teacher appears, and the background is the } \\
\text { weight map. } \\
\text { Animation shows all the weights. }\end{array}$ & $\begin{array}{l}\text { With comprehensive consideration of } \\
\text { transport, distance, topographical } \\
\text { features, we can calculate weight. }\end{array}$ & $\begin{array}{l}\text { According to comprehensive consideration of the } \\
\text { transportation conditions, distance, topographical } \\
\text { features, we should draw all the possible routes, and } \\
\text { calculate the weight of these routes according to the } \\
\text { length. These weighted routes constitute the set of edges } \\
\{\mathrm{E}\} \text {. }\end{array}$ \\
\hline 14 & $\begin{array}{l}\text { Teacher appears, and the background is the } \\
\text { PPT of the concept of minimum spanning tree }\end{array}$ & $\begin{array}{l}\text { The characteristics of the minimum } \\
\text { spanning tree }\end{array}$ & $\begin{array}{l}\text { What are the characteristics of the minimum spanning } \\
\text { tree? To set } \mathrm{N}=(\mathrm{V},\{\mathrm{E}\}) \text { be a connected network, and } \mathrm{U} \\
\text { is a non-empty subset of vertex set } \mathrm{V} \text {. If }(\mathrm{u}, \mathrm{v}) \text { is the edge } \\
\text { with the least weight, where } \mathrm{u} \in \mathrm{U}, \mathrm{v} \in \mathrm{V} \text { - } \mathrm{U} \text { exists a } \\
\text { minimum spanning tree with the edge }(\mathrm{u}, \mathrm{v}) \text {. }\end{array}$ \\
\hline 15 & Power engineer appears & $\begin{array}{l}\text { The solving steps of minimum } \\
\text { spanning tree }\end{array}$ & $\begin{array}{l}\text { We know the characteristics, what method can be used to } \\
\text { find the minimum spanning tree with this characteristic? }\end{array}$ \\
\hline 16 & Teacher appears, and the background is office & Prim algorithm & $\begin{array}{l}\text { We should use Prim algorithm to find the minimum } \\
\text { spanning tree one by one. }\end{array}$ \\
\hline 17 & $\begin{array}{l}\text { Teacher appears, and it shows the PPT of } \\
\text { Prim algorithm }\end{array}$ & The steps of Prim algorithm & $\begin{array}{l}\text { The first step, it should select a starting crunode. } \\
\text { The second step is to draw a circle around this crunode, } \\
\text { select the crunode with the smallest weight through the } \\
\text { edges of this circle, and connect this crunode with the } \\
\text { edge into the current minimum spanning tree. } \\
\text { The third step, it should regard the crunode of current } \\
\text { minimum spanning tree as an entirety, and repeat the } \\
\text { second and third steps until all the crunodes are collected } \\
\text { in the minimum spanning tree. }\end{array}$ \\
\hline 18 & $\begin{array}{l}\text { Teacher appears, it shows the steps of simple } \\
\text { map }\end{array}$ & $\begin{array}{l}\text { It should select a starting crunode } \mathrm{A} \\
\text { and the edge (A, C) with the lowest } \\
\text { cost, merge this edge into TE, and } \\
\text { merge the crunode } \mathrm{C} \text { connected to } \\
\text { this edge into U. And it could repeat } \\
\text { this process to find the minimum } \\
\text { spanning tree. }\end{array}$ & $\begin{array}{l}\text { First, it should select a starting crunode A. In this lines of } \\
\text { this crunode connecting to the other crunodes, it should } \\
\text { select the least costly edge (A, C), and merge this edge } \\
\text { into TE. And then, it should merge the crunode C } \\
\text { connected to the edge into U. Then, we can repeat this } \\
\text { process, take the crunodes in U set as an entity. And we } \\
\text { can select the least costly edge (C, E) with the crunodes } \\
\text { in the entity connected to the other crunodes in (VU), } \\
\text { merge it into TE, merge E into U, regard ACE as a entity, } \\
\text { merge (E, D) into TE, and merge D into U. Finally, we } \\
\text { should select (E, B) into TE, merge B into U, U =V, } 5 \\
\text { vertices and } 4 \text { edges. Then, we obtain the minimum } \\
\text { spanning tree. }\end{array}$ \\
\hline 19 & Teacher appears & $\begin{array}{l}\text { We can use Prim algorithm to find } \\
\text { the laying path of the optical cable. }\end{array}$ & $\begin{array}{l}\text { We can use Prim algorithm to find the laying path of the } \\
\text { optical cable. }\end{array}$ \\
\hline 20 & $\begin{array}{l}\text { Power engineer and the demonstration } \\
\text { process of animation map }\end{array}$ & $\begin{array}{l}\text { We should select the starting crunode } \\
\text { and the edge with the lowest weight }\end{array}$ & $\begin{array}{l}\text { We should select the starting crunode and the edge with } \\
\text { the lowest weight. And then, we repeat this process. We } \\
\text { can find out the laying path of the optical cable. }\end{array}$ \\
\hline 21 & $\begin{array}{l}\text { Leader appears, coffee, and virtual } \\
\text { background }\end{array}$ & $\begin{array}{l}\text { Can Prim algorithm solve other } \\
\text { problems? }\end{array}$ & $\begin{array}{l}\text { We solve the problem. Prim algorithm is really easy to } \\
\text { use. And can this algorithm solve other problems? }\end{array}$ \\
\hline 22 & $\begin{array}{l}\text { Traffic police appears and PPT of traffic } \\
\text { articles }\end{array}$ & Application of transportation & $\begin{array}{l}\text { The minimum spanning tree has been applied in the } \\
\text { highway design, satellite navigation systems, urban bus } \\
\text { station design and other fields. }\end{array}$ \\
\hline 23 & $\begin{array}{l}\text { Financial analyst appears and PPT of } \\
\text { financial article }\end{array}$ & Financial applications & $\begin{array}{l}\text { The minimum spanning tree is also widely used in } \\
\text { securities analysis, financial system calculation and so on }\end{array}$ \\
\hline 24 & $\begin{array}{l}\text { Power engineer appears and PPT of power } \\
\text { article }\end{array}$ & The application of electric power & $\begin{array}{l}\text { The minimum spanning tree can also be used in power } \\
\text { grid configuration, power system design and so on. }\end{array}$ \\
\hline 25 & Leader appears and PPT of other application & Other applications & $\begin{array}{l}\text { The minimum spanning tree can be used in the medical } \\
\text { field, the image field, the coal field and so on. }\end{array}$ \\
\hline 26 & $\begin{array}{l}\text { Teacher appears and PPT of algorithm } \\
\text { optimization }\end{array}$ & Algorithm optimization & $\begin{array}{l}\text { Many experts are also constantly working on faster and } \\
\text { more stable algorithms of the minimum spanning trees. }\end{array}$ \\
\hline 27 & Teacher appears and PPT of thinking & $\begin{array}{l}\text { The crunode is included in Prim } \\
\text { algorithm. What is the algorithm of } \\
\text { the edge? }\end{array}$ & $\begin{array}{l}\text { We can use the Prim algorithm to solve the minimum } \\
\text { spanning tree to find the optimal solution one by one. } \\
\text { And then, can we find the minimum spanning tree } \\
\text { through the size of the edge? }\end{array}$ \\
\hline 28 & Conclusion & $\begin{array}{l}\text { to apply what they have learned, to } \\
\text { study endlessly and to be an elite } \\
\text { talent in new era }\end{array}$ & Prim algorithm, you get it? \\
\hline
\end{tabular}




\section{The Main Production Software and Its Use}

1) PowerPoint 2010: PowerPoint 2010 will be used to explain the contents of courseware. All the animations are set to automatically play, and we should control the time. We can install fonts with subtitles artistic effects in the computer, such as FZMiaoWu, mini-Jianqi and so on. We should make full use of the art word and its gradient mode of PowerPoint 2010 to design titles and captions used in the subtitles. And the background color of these designed fonts is set to be transparent. We should save it as PNG image.

2) Hand-drawn Animation Software EasySketchpro2: We should set the background color to be pure green in EasySketchpro2 to facilitate post-keying processing. We should insert the text or picture to be hand-drawn cartoon design, and generate hand-drawn animation, and then save it into MP4.

3) Voice Editing Software CoolEdit: We should use CoolEdit software to record the sound of quiet indoor in a city. As the noise elimination sample, the sound is recorded according to the steps of the instructional design, and we should number it in sequence, record and cut out unwanted parts, and the noise is saved into the sound folder.

4) Animation Assistant Software CrazyTalk_Pro: In CrazyTalk_Pro, we could load a white image of the teacher. And the image must be a positive photo. The teacher should smile, and he couldn't show teeth. In these photos, it can't appear green or similar colors. Then, we could set the characters' facial features match with the steps, introduce pre-production of good sound, set the background to be pure green, and generate the video.

5) Screen Recording Software-Super Screen Recording 8.0: We could set the microphone, use the CoolEdit software to record the voice, and set the playback sequence of PPT animation. In super screen recording 8.0, we couldn't record the sound and the mouse. Each scene has been recorded. The sound exactly matches the animation for later integration editing.

6) Green Screen Keying Software Adobe Ultra CS3: We could introduce the video to be choked into Adobe Ultra CS3, use the keying menu to make keying, and import the virtual scenes into the video with the virtual scene menu to make the video more appealing.

7) Interactive Design Software Adobe Captivate 8: We should introduce the produced title and the animated PPT courseware. And then, we can add keying processed interpretation video for PPT. In the middle and ending sections, we could use quiz menus of Adobe Captivate 8 to design exercises with interactive functions.

\section{Teaching Micro-class Production}

1) The Preparation of the Materials: We could cut out the map in the context through Baidu Map, select the map near by the location of the school which the students are familiar with. We could search the designed characters by Baidu map to determine that we have the leader, traffic police, electrical engineers, financier, national defense warrior and teachers. The whole picture belongs to the cartoon style, and the design of fonts and backgrounds are based on cartoon-style images. All the subtitles are produced by PowerPoint 2010.

2) Material Production Process: We could make PPT in accordance with the steps of instructional design. After playing PPT, we could open Super Recording 8.0, and record the sound in accordance with the design of the line while playing PPT animation. We would record an animation and voice of each screen. In CrazyTalk_Pro, we could set the facial features of the characters in accordance with the order of appearance. Then, we could import sound, and generate green screen video. In the end, we would save this video. We could use Adobe Ultra CS3 to make the keying processing of all animation teaching assistant video. Then, we would save the video as 24-bit keying source files. Then, we should convert the video format into flv format.

3) Compilation and Integration: We should import all the materials into Adobe Captivate 8 by turns. And the keying video should be introduced as multi-track animation. We should synchronize the recorded PPT videos with the screens in time, and finish the compilation of the exercises in the last part of the teaching video. Also, we should arrange the order of the timeline materials. And then, we can publish the works in video format.

\section{TEACHING PRACTICE}

Totally 80 syngenic students have been chosen for the teaching practice. 40 students carry out the classroom teaching of the course content. 40 students complete the learning of the minimum spanning tree through the microclass in spare time. 30 students of the classroom teaching group are able to master process of solving the minimum spanning tree. 33 students of micro-class teaching group master the process of solving the minimum spanning tree. Students of the classroom teaching group use micro-class teaching. 39 students are able to master the solving process of the minimum spanning tree. 80 students in two groups, 73 students think that the visual situated-problem micro-class is more vivid and interesting. It's easy to understand and remember. The learned knowledge can be associated with daily life. Five students think that classroom teaching can master the minimum spanning tree related knowledge, and there is little difference between the two methods.

\section{CONCLUSION}

The general process of visual situation-problem-based teaching method is as the followings. We could select the knowledge points suitable for the situation-problem-based teaching method, make situation-problem-based teaching design for the knowledge points, write teaching design scripts according to the designed situations, compile the situations with using all kinds of software, and integrate them into visual materials according to the order of the scripts. Finally, we could integrate materials and publish works. 
The teachers could use the situated-problem teaching method to make teaching design, use all kinds of software to make the teaching resources that students can learn independently, load these resources into the network teaching platform, WeChat public platform and MOOC platform. And the students can learn new knowledge at any time and in any place. Then, the students could review knowledge and improve learning outcomes.

\section{REFERENCES}

[1] Li Jilin. To develop child language with situational teaching [J]. Journal of The Chinese Society of Education. 1995 (12): 44-47

[2] Lv Chuanhan, Wang Bingyi. The theoretic base of teaching and learning of primary and secondary "mathematical situation and questions" and implementation strategies [J]. Journal of Guizhou Normal University (Natural Sciences). 2007 (02): 95-100

[3] Luo Zengru. On the cases and understanding of scene introduction [J]. Mathematics Bulletin. 2009 (4): 1-6

[4] Peng Yufeng. The application research of the situated-problem teaching in junior high school [D]. Zhangzhou. Minnan Normal University, 2015

[5] Li Mang. Visual teaching design methods and applications [J]. Eeducation Research. 2013

[6] Zhao Huichen, Wang Shuyan. A new viewpoint of knowledge visualization applied to subject teaching-An interview with professor Martin Epsilon, a pioneer of knowledge visualization in Switzerland [J]. Open Education Research. 2014 (04): 4-10 